\title{
Supply Chain Management Improvement Through Strategic Planning for Human Resources in the Industrial Revolution 4.0
}

\author{
Nida Hanin Dary ${ }^{1 *}$, Ismi Dwi Astuti Nurhaeni², Didik Gunawan Suharto ${ }^{2}$ \\ ${ }^{1}$ Master Program in Public Administration Department, Faculty of Social and Political Sciences, Universitas Sebelas \\ Maret, Surakarta, Indonesia \\ ${ }^{2}$ Public Administration Department, Faculty of Social and Political Sciences, Universitas Sebelas Maret, Surakarta, \\ Indonesia \\ *Corresponding author. Email: nidahanin@gmail.com
}

\begin{abstract}
Human resources in Indonesia are required to be improved to be internationally competitive, actively synchronized, and innovative with rapidly developing information technology to support the quality of Supply Chain Management (SCM) and also support sustainable development. Nevertheless, in the era of the Industrial Revolution 4.0, Supply Chain in Indonesia was increasingly confronted with the challenges of international competition in terms of innovation and technology. In addition to increasing the quality of technology to improve Supply Chain Management (SCM), it is necessary to do strategic planning of human resources to equip the suppliers with international capacity in using technology that has been provided by the government to innovate or cooperate with other countries. This study aims to examine the strategic role of human resource management to produce human resources with international capacity, innovative, and able to support the improvement of Supply Chain Management (SCM) in Indonesia in facing the challenges of the Industrial Revolution 4.0. This research was conducted using qualitative research methods with a systematic literature review approach. Efforts to increase human resource capacity are carried out by creating human resource strategic planning based on analysis of the situation and potential of human resources, then training and development are carried out based on international standardization.
\end{abstract}

Keywords: supply chain management, strategic planning, human resources, Industrial Revolution 4.0, Indonesia

\section{INTRODUCTION}

The era of the industrial revolution 4.0 brought all aspects of people's lives, businesses, and government to increasingly develop with high interconnectivity. This also applies to the increase in Supply Chain Management (SCM) in Indonesia which has also begun to enter the industrial revolution 4.0. Supply chain improvement can be done more optimally with connectivity to automation and big data that will provide effectiveness and efficiency at work. To improve services to public consumers in terms of quality and effectiveness and to improve operations, supply chains need to be improved given that the competition faced by suppliers in Indonesia is by the emergence of other suppliers from abroad who have capacities above the average domestic suppliers [1]. Therefore, the Indonesian government also needs to move to increase the capacity of Supply Chain Management (SCM) in Indonesia both in terms of completeness resources for the development of Supply Chain Management (SCM) in the industrial revolution 4.0, as well as to increase human resources so that they have the capacity can offset the performance of the industrial revolution 4.0. cooperation between the government and the private sector is also needed as a strategy that is driven by service providers from the government and the private sector which is then combined with the completeness of knowledge, abilities, and resources over a long time [2].

Today, the old paradigm which states that countries compete with one another and compete to defeat one another has shifted to a period of collaboration. A country cannot run alone in achieving its country's goals effectively and efficiently. Therefore, the government will cooperate with the private sector and jointly with the surrounding countries to achieve an effective and efficient improvement and development of the country. The improvement in the quality and capacity of human resources is supported by globalization that is happening now, which facilitates cooperation between countries and suppliers to improve human resources in Supply Chain Management (SCM) to be able to compete internationally at the same time by utilizing cross-border cooperation, and regional [3]. Collaborative activities in the global era such as government efforts to provide facilities and resources for suppliers in Indonesia to improve human resources in Supply Chain Management (SCM) have an impact on the high demands of organizational performance where human resources in Supply Chain Management (SCM) must be able to adjust its capacity with the technology used in the era of the industrial revolution 4.0 and must be able to keep pace with the pace of development that is happening on the 
international scene. The role of employees is greatly influenced by the increased collaboration carried out by their organizations.

Human resources in Indonesia need to be improved to support the quality of Supply Chain Management (SCM) so that they are internationally competitive and actively synchronized and innovative with rapidly developing information technology that can support sustainable development [4]. Nevertheless, in the era of the Industrial Revolution 4.0, Supply Chain in Indonesia was increasingly confronted with the challenges of international innovation and technology competition. In addition to improving the quality of technology to improve Supply Chain Management (SCM), it is necessary to do strategic planning of human resources to bridge suppliers with international capacity in using technology that has been provided by the government to innovate or cooperate with other countries. This study aims to examine the strategic role of human resource management to produce human resources with international capacity, innovative, and able to support the improvement of Supply Chain Management (SCM) in Indonesia in facing the challenges of the Industrial Revolution 4.0.

\section{METHODS}

This research was conducted using qualitative research methods with a systematic literature review approach. Efforts to increase the capacity of human resources are carried out by making strategic human resource planning based on an analysis of the situation and potential of human resources, then education and training are carried out to increase the capacity of human resources in Supply Chain Management (SCM) based on international standards. This research was conducted with a literature study method from a book on learning about human resource management, journals and articles on previous research in Supply Chain Management (SCM), industrial revolution 4.0, and human resource management, as well as news, adapted from websites related to Supply. Chain Management (SCM) and human resource management. Data is collected from journal articles, country reports, and previous research. Then the data that has been collected is processed with the theory of human resource management and sound governance. Thus, generating new data about the needs of research subjects which are then analysed again to design strategic planning as a form of innovative solutions to the ongoing development of human resource management in Indonesia's Supply Chain Management (SCM) in the challenges of the Industrial Revolution 4.0.

\section{RESULTS AND DISCUSSION}

Indonesia, which is incorporated in ASEAN, has moved its people towards the ASEAN Economic Community. Not only promoted by the public at large, the direction of the Indonesian business and economic sector is also carried out to be ready to compete in free trade international markets. The PPP that drives the public and private sectors in the development and improvement of projects in Indonesia began to lead to international cooperation as well as in Supply Chain Management (SCM) in Indonesia. Good collaboration in technology transfer, education, and human resources. However, the performance of human resources in Supply Chain Management (SCM) in Indonesia cannot yet be said to be effective in the development of globalization. This is indicated by the existence of new autonomous regions that are not accompanied by adequate human and financial capacity as well as the continuing problems of guarantees, fulfilment of financing requirements, institutional capacity and inadequate cooperation [5]. While the human resource development index based on skills in Indonesia is recorded in the Human Development Reports by the United Nations Development Program (UNDP) of $40.8 \%$ of talented employees [6]. While developing countries in Southeast Asia such as Thailand (37.4\%), the Philippines (30.6\%), Laos (33.2\%), Vietnam (32.8\%), Myanmar (17.7\%), and Cambodia (9.7\%) is still below the index value of employees who have skills in Indonesia. Even so, Indonesia still has to compete with other Southeast Asian countries that have an employee index that has high skills far above Indonesia such as Malaysia (67.3), Brunei Darussalam (79.1\%), and Singapore (81.7\%) [7]. The figure shows the large capacity of human resources in Indonesia who have the skills to be able to work optimally and effectively from both the public and private sectors. So Supply Chain Management (SCM) should be able to run well, considering that Indonesia has an index of human resource development based on skills that are quite high. Problems arise when human resources with skills are not a major obstacle to the effectiveness of the performance of human resources in Supply Chain Management (SCM), but rather how human resources with qualified skills can be arranged so that the effectiveness of performance in the realm of globalization can be created. The challenges of human resource management in Indonesia in facing globalization and internationalization are even greater considering that ASEAN countries are now competing to become more flexible and dynamic with global developments, especially in the environment of their neighbours. ASEAN countries learn from each other about the movements and developments of their neighbours, so that they can prepare themselves to collaborate in international partnerships.

The launch of the 4.0 industrial revolution in Indonesia, with the automation of a production system that utilizes technology and big data, led Indonesia to move more openly in international cooperation to support the implementation of the industrial revolution 4.0. As in the paradigm of sound governance that is more comprehensive than the concept of good governance and other concepts, the strength of global or international governance is an important factor influencing a country in achieving its country's goals [8]. However, Indonesia as a multicultural country and has many cultures has its own challenges in its human resources in facing globalization and the openness of international cooperation which is also carried out on Supply Chain Management (SCM) in Indonesia.

Work effectiveness can be achieved by increasing work motivation and commitment [9]. Work motivation is needed by employees to spur responsiveness and desire to continue to compete in their work. Motivation is also very important 
given the encouragement of collaboration between countries is increasingly strengthened so that the willingness and ability to continue to learn and develop for employees must continue to be improved. With work motivation, human resources in Supply Chain Management (SCM) in Indonesia can easily be encouraged to develop and innovate in the advancement of technology, information, and knowledge needed by Supply Chain Management (SCM) in Indonesia in the implementation of independent work projects or cooperation that uses the transfer of knowledge and technology with foreign parties. Motivation component consists of 3 things, namely, ignition where someone will have the initiative or desire to achieve a goal, the direction is an action taken by someone in achieving its goals, and the last is the maintenance or maintenance of one's sari behaviour until the goal is achieved [10]. These three things should be emphasized by human resource managers in Supply Chain Management (SCM) in Indonesia in Indonesia to ignite the work motivation of employees to support the effectiveness of Supply Chain Management (SCM) in Indonesia in the collaboration sector and competition in the international free market. With work motivation, skills possessed by employees can be effectively channelled and developed in line with organizational goals.

Commitment is also an important factor in increasing work effectiveness and should be an important concern for human resource managers in the Supply Chain Management (SCM) sector in Indonesia in the face of globalization. The commitment of employees can be obtained by the way human resource managers regulate the organizational climate in it so that the working atmosphere is created with good and conducive conditions so that it can bring its employees to high work commitments [11]. In facing the globalization era that is very dynamic, flexible, and fluctuating, employee commitment is needed to encourage the ability to learn and develop in line with international dynamics that will rub against organizational action in Supply Chain Management (SCM) in Indonesia. Pressure arising from improved performance by Supply Chain Management (SCM) in Indonesia with Multi-National Corporation (MNC) and with other governments will be even greater than the pressure on company employees or organizations that only operate within the internal sphere Indonesia. Demands for performance adaptation with foreign companies are also issues that must be dealt with. Thus, employee commitment needs to be increased to avoid employee absences and turnover. Commitment is needed so that employees in facing pressures and demands that arise along with the absorption of globalization values in Supply Chain Management (SCM) in Indonesia which is getting bigger and more complex, employee commitment in determination, willingness, and loyalty in working can be maintained and also increased. So, it is expected that the effectiveness of performance can be achieved without the constraints of globalization pressures and demands.

The strategic planning needed to increase the capacity of human resources in Supply Chain Management (SCM) in Indonesia is an increase in the capacity of human resources about Supply Chain Management (SCM) through training, seminars, and capacity building [12]. The other most important thing is to increase understanding about increasing interconnection in Supply Chain Management (SCM) in Indonesia to existing human resources in implementing agencies to support clear and proper communication with consumers. This is certainly a way of forming human resources with strategic planning management which is then directed at education and training on important aspects of coordination, communication, and understanding basic values to the value of detail in Supply Chain Management (SCM) in Indonesia. Initial education is needed for new human resources as their knowledge of Supply Chain Management (SCM) in Indonesia and the processes behind the scheme. Besides, education about good and proper communication and coordination procedures needs to be provided since the beginning of the recruitment of human resources. However, education and the provision of knowledge about Supply Chain Management (SCM) in Indonesia and appropriate communication and coordination models also need to be given to human resources that previously existed in the institution. It also does not limit the implementation of ongoing seminars and capacity building in the hope of deepening the knowledge of human resources and instilling the main points of substance needed in their daily performance in Supply Chain Management (SCM) in Indonesia.

The provision of training is also needed in a strategic plan to increase the capacity of human resources in Supply Chain Management (SCM) in Indonesia. The training provided can be in the form of coordination training through a capacity building which is carried out sustainably and continuously. This is intended to familiarize human resources in Supply Chain Management (SCM) in Indonesia in coordinating with organizations from other countries, as well as with the governments of other countries that are partners in Indonesia Supply Chain Management (SCM) cooperation in Indonesia. The training will develop the potential of human resources towards international standards in terms of coordination. The method used is to implement a more effective and directed coordination method in the Supply Chain Management (SCM) body in Indonesia in training, as well as accustoming the existing human resources to maintain coordination both vertically and horizontally in Supply Chain Management (SCM) in Indonesia. Indonesia. With international standard coordination, Supply Chain Management (SCM) in Indonesia will run well. In this era of globalization, Indonesia cannot walk alone towards infrastructure development, but the need for cooperation with other countries and positive interdependence to improving the performance of Supply Chain Management (SCM) in the country. Thus, smooth coordination is needed in establishing partnership project relationships with foreign parties. Besides, the importance of training and briefing for communication also needs to be addressed. This affects the smooth performance of coordination carried out in the implementation of Supply Chain Management (SCM) in Indonesia.

Facing the Industrial Revolution 4.0 era, Supply Chain Management (SCM) in Indonesia is also faced with information technology challenges that affect the coordination and communication dynamics of Supply Chain Management (SCM) institutions in Indonesia with 
foreign investors. Thus, education, training, and development in Supply Chain Management (SCM) human resources in Indonesia needs to be improved for the development of Supply Chain Management (SCM) sustainability in Indonesia. Besides, by increasing performance by following the development of the Industrial Revolution 4.0, Supply Chain Management (SCM) in Indonesia can run more easily, effectively, and efficiently. Communication arranged as the influence of the entry of information technology in Supply Chain Management (SCM) in Indonesia will accelerate the coordination of the Supply Chain Management (SCM) work program in Indonesia which is to be implemented jointly between Indonesia and investors from foreign countries.

\section{CONCLUSION}

Strategic planning needed to increase the capacity of human resources in Supply Chain Management (SCM) in Indonesia include increasing the capacity of human resources about Supply Chain Management (SCM) in Indonesia through training and supplies, seminars, and capacity building as a potential resource development human being is of an international standard. Another most important thing is to increase understanding of Supply Chain Management (SCM) policies in Indonesia for human resources in implementing agencies to support clear and precise communication and coordination with investors. This is certainly a way of forming human resources with strategic planning management which is then directed at education and training on important aspects of coordination, communication, and understanding basic values to the value of detail in Supply Chain Management (SCM) in Indonesia

\section{REFERENCES}

[1] A.-N. El-Kassar and S. K. Singh, "Green innovation and organizational performance: The influence of big data and the moderating role of management commitment and HR practices," Technological Forecasting and Social Change, vol. 144, pp. 483-498, 2019.

[2] B. B. Keers and P. C. Fenema , "Managing risks in public-private partnership formation projects," International Journal of Project Management, vol. 36, no. 6 , pp. 861-875, 2018.
[3] L. B. Liboni, L. O. Cezarino, C. J. C. Jabbour, B. G. Oliveira, and N. O. Stefanelli, "Smart industry and the pathways to HRM 4.0: implications for SCM," Supply Chain Management: An International Journal, vol. 24, no. 1, pp. 124-146, 2019.

[4] M. Madani and P. Wajeetongratana, "The Effects of Culture and Human Resources Management Policies on Supply Chain Management Strategy," Polish Journal of Management Studies, vol. 19, no. 1, pp. 235-248, 2019.

[5] B. Rifai, "Kendala implementasi kerja sama pemerintah swasta (kps) kelistrikan dan kebutuhan perbaikan kebijakan," Jurnal ekonomi dan pembangunan, vol. 24, no. 1, pp. 51-66, 2016.

[6] "Human Development Reports," UNDP. [Online]. Available: http://hdr.undp.org/en/2018-update. [Accessed: May-2019].

[7] A. Farazmand, "Sound Governance: Engaging Citizens through Collaborative Organizations," Public Organization Review, vol. 12, no. 3, pp. 223-241, 2012.

[8] Z. Senyucel, Managing the human resource in the 21 st century. Zorlu senyucel \& Ventus publishing aps., 2009.

[9] I. Suprapanca, Laporan pengkajian hukum tentang penerapan sistem public privat partnership (ppp) dalam proyek pembangunan energi listrik . Jakarta: badan pembinaan hukum nasional kementerian hukum dan hak asasi manusia RI, 2015.

[10] R. Kalangi, "Pengembangan sumber daya manusia dan kinerja aparat sipil negara di kabupaten Kepulauan Sangihe Provinsi Sulawesi Utara.," Jurnal LPPM bidang Ekososbudkum, vol. 2, no. 1, pp. 1-18, 2015.

[11] A. Prihantoro, "Peningkatan kinerja sumber daya manusia melalui motivasi, disiplin, lingkungan kerja, dan komitmen (studi kasus madrasah di lingkungan Yayasan Salafiyah, Kajen, Margoyoso, Pati),” Jurnal Unimus, vol. 8, no. 2, pp. 78-98, 2012.

[12] W. Xu, D. Furie, M. Mahabhaleshwar, B. Suresh, and H. Chouhan, "Applications of an interaction, process, integration and intelligence (IPII) design approach for ergonomics solutions," Ergonomics, vol. 62, no. 7, pp. 954-980, Sep. 2019. 